Technical Paper

\title{
Evaluation and Comparison of Intercontinental Renewable Energy Transportation System
}

\author{
Yuki IsHimoto, Kenzo FUKUDA and Ko SAKATA \\ (Received November 1, 2014)
}

\begin{abstract}
The concept in which renewable energy is imported from foreign countries or other regions using energy carriers should be strongly promoted from the viewpoint of energy security and climate change in addition to development of other energy technologies. The apparent economic comparison among electricity and these chemicals as energy carriers was done in our earlier studies. However the costs in our earlier studies were relatively high compared with the present electricity prices. In this paper, cost reduction of these systems is described. By setting parameters properly, the re-electrification cost in Japan is reduced to the range of the present electricity price in Japan. Therefore, large scale demonstration and deployment projects and/or financial incentives for these systems are necessary to commercialize these systems.
\end{abstract}

エネルギーセキュリテイの向上や気候変動への対策として, 賦存量が多〈かつ安価に利用可能な海外の再生可能エネルギー由来 の電力を我が国へ輸送するエネルギーキャリアシステムについて考察した。エネルギーキャリアは, 電力, 液体水素, トルエン/メチ ルシクロヘキサン系有機八イドライドを選定した。これまでの検討では, このシステムを用いた日本に扔り再電力化コストは, 日本に おける電力コストを超えていた。今回の 検討では, 設備規模の適切な設定やプラント寿命の考察等により, 日本の電力コストの範囲 内までコストを低減できることが示唆された。

\section{Key Words}

Energy carrier, HVDC, Liquefied hydrogen, Methylcyclohexane

\section{Introduction}

Renewable energy of high energy density is distributed in specific regions though renewable energy is broadly available on the Earth. For example, suitable areas for electric generation by wind turbines are limited. Energy density of renewable energy is closely related to the cost of energy conversion. The concept in which renewable energy is imported from foreign countries or other regions using hydrogen or other chemicals as energy carrier should be strongly promoted from the viewpoint of energy security and climate change in addition to development of other energy technologies. There are a variety of earlier studies ${ }^{1) ~ 8)}$ using electricity, liquefied hydrogen (LH2) and organic chemical hydride $(\mathrm{OCH})$ as carriers for renewable energy. However transportation distance of the literatures 1) 3) 5) 8)

The Institute of Applied Energy

1-14-2, Shinbashi, Minato-ku, Tokyo 105-0003, Japan was less than $5,000 \mathrm{~km}$ because the scope of these studies are thought to be transportation between European and neighbor regions. The maximum transportation distance considered was $20,000 \mathrm{~km}$ in WE-NET 2) ${ }^{4)}$. However evaluation of organic chemical hydride was not done. The apparent comparison among electricity and these chemicals as energy carriers was done from economical viewpoints in our earlier studies ${ }^{91}{ }^{10}$. However the re-electrification costs in our earlier studies were relatively high compared with the present electricity price in Japan. The re-electrification cost in Japan includes the cost from renewable energy in foreign regions to hydrogen power plant in Japan. In this paper, cost reduction of these systems using chemical energy carriers is described.

This study was partly presented in the GRE2014. 


\section{Design of Intercontinental Renewable Energy Transportation Systems}

\subsection{Selection of energy carriers}

Advantages and disadvantages of electricity and chemicals as energy carriers are shown in Table 1. Electricity should be transmitted via cables because renewable energy is generally available in the form of electricity. However the loss of electricity increases with the distance. The long distance electric transmission technology on the order of several thousands of kilometers has been established recently ${ }^{10}$. Conversion of electricity into chemicals requires various facilities such as reactors and storage tanks. Therefore in the short range transportation, chemicals are thought to be inadequate for energy carriers of renewable energy.

Electricity and two chemicals (liquefied hydrogen and organic chemical hydride (toluene/ methylcyclohexane)) were selected as energy carriers of renewable energy for long distance transportation ${ }^{91}{ }^{10}$. The high voltage direct current (HVDC) technology was selected in order to transmit electricity for long distance.

\subsection{Conceptual design for intercontinental renewable energy transportation systems}

Conceptual design for intercontinental renewable energy transportation systems using electricity, liquefied

Table 1 Advantages and disadvantages of electricity and chemicals as energy carriers

\begin{tabular}{l|l|l}
\hline & \multicolumn{1}{|c}{ Advantages } & \multicolumn{1}{c}{ Disadvantages } \\
\hline Electricity & $\cdot$ Easy to utilize & $\begin{array}{l}\cdot \text { Difficult to store } \\
\cdot \text { Decrease with distance }\end{array}$ \\
\hline Chemicals & $\cdot$ Easy to store & $\begin{array}{l}\cdot \text { Large fixed cost } \\
\cdot \text { Transformation loss }\end{array}$ \\
\hline
\end{tabular}

hydrogen and organic chemical hydride was done. The source of renewable energy is assumed to supply electricity constantly for simplicity because the capacity ratio and the amplitude change of renewable energy depend on its characteristic. The boundary of evaluation and design is from the electric grid in foreign regions to the one in Japan. Fig. 1 shows a schematic diagram of intercontinental renewable energy transportation systems evaluated.

The unit capacity of designed systems was set to be $1 \mathrm{GW}$ so that designed systems play a large role in the power sector of Japan. The electricity cost of renewable energy supplied in the foreign countries was assumed to be $0.02 \mathrm{USD} / \mathrm{kWh}^{12}$. In the report of hydropower by IRENA, the electricity cost of large hydropower ranges 0.02 to 0.19 $\mathrm{USD} / \mathrm{kWh}$. In order to seek the potential of these systems, the lowest value was used in this paper.

Table 2 shows unit costs, unit capacitites, number of units and cost parameters of the LH2 system in the case of 10,000 km. The LH2 system contains a hydrogen production facility, a desalination plant, liquefaction plants, a loading port including storage tanks, tankers specialized for liquefied hydrogen (LH2 tanker), an unloading port including storage tanks and hydrogen-fired power plants. Table 3 shows unit costs, unit capacities, number of units and cost parameters of the $\mathrm{OCH}$ system in the case of $10,000 \mathrm{~km}$. The OCH system contains a hydrogen production facility, a desalination plant, hydrogenation plants, a loading port including storage tanks, tankers specialized for $\mathrm{OCH}$, an unloading port including storage tanks, dehydrogenation plants and hydrogen-fired power plants.

Details of each facility in the systems are described below. Hydrogen gas is produced in an electrolyzer using electricity from renewable energy. The capability of an electrolyzer unit is $500 \mathrm{Nm}^{3} /$ (h unit). The unit cost of

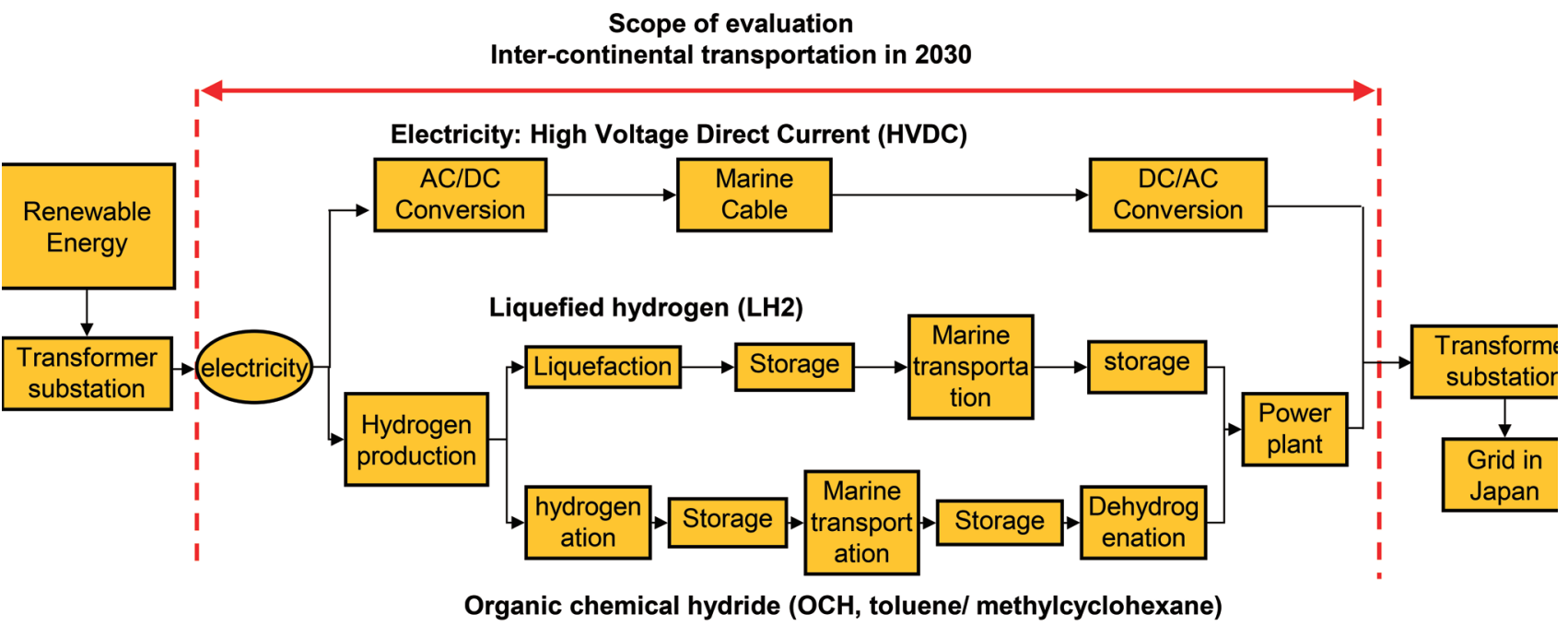

Fig. 1 A schematic diagram of intercontinental renewable energy transportation systems evaluated in this study 
Table 2 Unit cost, unit capacity, number of unit and cost parameter of the LH2 system in the case of $10,000 \mathrm{~km}$

\begin{tabular}{|c|c|c|c|c|c|c|c|}
\hline & Electrolysis & Desalination & Liquefaction & Loading port & LH2 Tanker & Unloading port & Power plant \\
\hline $\begin{array}{l}\text { Construction cost } \\
\text { (Million USD/Unit) }\end{array}$ & 1.25 & 155 & 224 & 411 & 301 & 490 & 1030 \\
\hline Capacity per unit & $500 \mathrm{Nm}^{3} / \mathrm{h}$ & $3.8 \mathrm{Mt} / \mathrm{yr}$ & $88 \mathrm{t} / \mathrm{d}$ & $76,400 \mathrm{~m}^{3}$ & $93,300 \mathrm{~m}^{3}$ & $79,170 \mathrm{~m}^{3}$ & $500,000 \mathrm{~kW}$ \\
\hline Number of Unit & 1073 & 1 & 13 & 2 & 6 & 4 & 2 \\
\hline $\begin{array}{l}\text { Investiment cost (Million } \\
\text { USD) }\end{array}$ & 1,341 & 155 & 2,910 & 823 & 1,805 & 1,958 & 2,060 \\
\hline $\begin{array}{l}\text { Durable year (year) (fixed } \\
\text { amount method) }\end{array}$ & 20 & 26 & 20 & 20 & 30 & 20 & 30 \\
\hline Discount rate (\%) & 5 & 5 & 5 & 5 & 5 & 5 & 5 \\
\hline Fixed asset tax rate (\%) & 1.4 & 1.4 & 1.4 & 1.4 & 1.4 & 1.4 & 1.4 \\
\hline Insurance cost rate (\%) & 0.6 & 0.6 & 0.6 & 0.6 & 0.6 & 0.6 & 0.6 \\
\hline $\begin{array}{l}\text { General and admin. cost } \\
\text { rate (\%) }\end{array}$ & 1 & 1 & 1 & 1 & 1 & 1 & 1 \\
\hline Labor cost rate (\%) & 0.3 & 0.3 & 0.3 & 0.3 & 0.3 & 0.3 & 0.3 \\
\hline Repair cost rate (\%) & 2.3 & 2.3 & 3.3 & 3.3 & 2.3 & 3.3 & 4.3 \\
\hline
\end{tabular}

Table3 Unit cost, unit capacity, number of unit and cost parameter of the $\mathrm{OCH}$ system in the case of $10,000 \mathrm{~km}$

\begin{tabular}{|c|c|c|c|c|c|c|c|c|c|}
\hline & Electrolysis & Desalination & Hydrogenation & $\begin{array}{c}\text { Loading } \\
\text { port }\end{array}$ & Tanker & $\begin{array}{c}\text { Unloading } \\
\text { port }\end{array}$ & Dehydrogenation & PSA & $\begin{array}{c}\text { Power } \\
\text { plant }\end{array}$ \\
\hline $\begin{array}{l}\text { Construction } \\
\text { cost (Million } \\
\text { USD/Unit) }\end{array}$ & 1.3 & 166 & 66 & 12 & 53 & 10 & 142 & 32 & 1,030 \\
\hline Capacity per unit & $500 \mathrm{Nm}^{3} / \mathrm{h}$ & 4.3 Mt/yr & $945,000 \mathrm{t} / \mathrm{yr}$ & $137,500 \mathrm{~kL}$ & $96,570 \mathrm{~kL}$ & 106,300 & $972,700 \mathrm{t} / \mathrm{yr}$ & $\begin{array}{r}4,500,000 \\
\mathrm{Nm}^{3} / \mathrm{d}\end{array}$ & $500,000 \mathrm{~kW}$ \\
\hline Number of Unit & 1209 & 1 & 7 & 3 & 10 & 10 & 7 & 3 & 2 \\
\hline $\begin{array}{l}\text { Investiment cost } \\
\text { (Bil USD) }\end{array}$ & 1,511 & 166 & 463 & 37 & 530 & 104 & 995 & 97 & 2,060 \\
\hline $\begin{array}{l}\text { Durable year } \\
\text { (year) (fixed } \\
\text { amount method) }\end{array}$ & 20 & 36 & 20 & 30 & 26 & 30 & 20 & 20 & 30 \\
\hline Discount rate (\%) & 5 & 5 & 5 & 5 & 5 & 5 & 5 & 5 & 5 \\
\hline $\begin{array}{l}\text { Fixed asset tax } \\
\text { rate (\%) }\end{array}$ & 1.4 & 1.4 & 1.4 & 1.4 & 1.4 & 1.4 & 1.4 & 1.4 & 1.4 \\
\hline $\begin{array}{l}\text { Insurance cost } \\
\text { rate (\%) }\end{array}$ & 0.6 & 0.6 & 0.6 & 0.6 & 0.6 & 0.6 & 0.6 & 0.6 & 0.6 \\
\hline $\begin{array}{l}\text { General and } \\
\text { admin. cost rate } \\
\text { (\%) }\end{array}$ & 1 & 1 & 1 & 1 & 1 & 1 & 1 & 1 & 1 \\
\hline $\begin{array}{l}\text { Labor cost rate } \\
(\%)\end{array}$ & 0.3 & 0.3 & 0.3 & 0.3 & 0.3 & 0.3 & 0.3 & 0.3 & 0.3 \\
\hline $\begin{array}{l}\text { Repair cost rate } \\
\text { (\%) }\end{array}$ & 2.3 & 2.3 & 3.3 & 3.3 & 2.3 & 3.3 & 3.3 & 2.3 & 4.3 \\
\hline
\end{tabular}

electrolyzer is 1.25 million USD ${ }^{13)}$. Then hydrogen gas is liquefied in the liquefaction plant and transferred to superinsulated storage tanks of approximately $80,000 \mathrm{~m}^{3} / \operatorname{tank}$ in the case of the LH2 system. The production rate of the liquefied plant is approximately 90t/day. The boil off gas (BOG) from liquefied hydrogen is back to the liquefaction plant by the BOG compressor. The storage capacity in the loading port is set to be equivalent to 1.5 times the capacity of the tanker. Liquefied hydrogen is transferred to the tanker specialized for liquefied hydrogen, the volume of which is approximately $100,000 \mathrm{~m}^{3}$. All lost gas caused by BOG during shipping are utilized as a fuel for propulsion. Liquefied hydrogen is unloaded to storage tanks from the tanker at an unloading port. The transfer loss (flash loss) the rate of which is $1.3 \%$ was taken into account. The volume of the storage tank is almost same in the loading port. Liquefied hydrogen is vaporized in the vaporizer and transferred to the power plant. The storage capacity in the unloading port is set to be the quantity equivalent to 20 days for the power plant and a half of an interval of 
tankers. For example, the storage capacity is 25 days in the case that the interval of tankers is 10 days. Hydrogen gas combusts in the hydrogen combustor and finally generates electricity to the grid in Japan. The output power is set to be $500 \mathrm{MW}$ per a power plant.

In the OCH system, the capacities of hydrogenation and dehydrogenation plants are approximately one million tons per year. Toluene/ methylcyclohexane are stored in tanks of approximately 140,000 and 100,000 kL/tank in the loading and unloading ports, respectively. They are transferred by the tanker, the volume of which is approximately $100,000 \mathrm{~kL}$. Heavy oil is utilized for the fuel for the tanker. $\mathrm{MCH}$ is unloaded to storage tanks from the tanker at an unloading port. The volume of the storage tank is the same in the loading port. $\mathrm{MCH}$ is decomposed to hydrogen and toluene in the dehydrogenation reactor. Heavy oil is utilized for the endothermic dehydrogenation reaction. Then hydrogen are compressed and transferred to the hydrogen power plant.

\subsection{Boundary conditions}

The conceptual design and evaluation were done on the assumption that the system is available in around 2030. For simplicity the source of renewable energy is assumed to supply electricity without any variation in voltage and current because the capacity ratio and the amplitude change of renewable energy depends on its own characteristics. The boundary of evaluation and design is from the electric grid in foreign regions to the one in Japan. Fig. 1 shows a schematic diagram of inter-continental renewable energy transportation systems evaluated in this study. The evaluated distance ranged from $2,300 \mathrm{~km}$ to $20,000 \mathrm{~km}$.

\subsection{Method of cost evaluation}

The method of cost evaluation used in NEA/IEA ${ }^{14)}$ is employed. The equation of the livelized cost of electricity is expressed as follows;

Electricity cost of the system $=\Sigma_{n} C_{n}$

$C_{n}=\frac{\sum_{t}\left[\left(F_{n, t}+V_{n, t}\right)(1+r)^{-t}\right]}{\sum_{t} E_{t}(1+r)^{-t}}$

$\mathrm{F}_{\mathrm{n}, \mathrm{t}}=\mathrm{C}_{\text {dep_n, } \mathrm{n}}+\mathrm{C}_{\text {tax_nn,t }}+\mathrm{C}_{\text {ins_n,t }}+\mathrm{C}_{\text {gen_n,t }}+\mathrm{C}_{\text {lab_n,t }}+\mathrm{C}_{\text {rep_n, t }}$

$\mathrm{V}_{\mathrm{n}, \mathrm{t}}=\mathrm{C}_{\text {elec }}+\mathrm{C}_{\text {fuel_n, } \mathrm{t}}+\mathrm{C}_{\text {tol_ } \mathrm{n}, \mathrm{t}}$

$\mathrm{C}_{\text {dep_n }, \mathrm{t}}=\mathrm{C}_{\text {const_n }} / \mathrm{Y}_{\text {durable_n }}$

$\mathrm{C}_{\text {tax_nn,t }}=\mathrm{r}_{\text {tax }} \times \mathrm{V}_{\text {book_n,t }}$

$\mathrm{C}_{\text {ins_n,t }}=\mathrm{r}_{\text {ins }} \times \mathrm{C}_{\text {const_n }}$

$\mathrm{C}_{\text {gen_n } \mathrm{n}, \mathrm{t}}=\mathrm{r}_{\text {gen }} \times \mathrm{C}_{\text {const_n }}$

$\mathrm{C}_{\text {lab_n,t }}=\mathrm{r}_{\text {lab }} \times \mathrm{C}_{\text {const_n }}$

$\mathrm{C}_{\text {rep_n } \mathrm{n}, \mathrm{t}}=\mathrm{r}_{\text {rep }} \times \mathrm{C}_{\text {const_ } \mathrm{n}}$ where,

$\mathrm{F}_{\mathrm{n}, \mathrm{t}}$ : fixed cost in the facility $\mathrm{n}$ and the year $\mathrm{t}$;

$\mathrm{V}_{\mathrm{n}, \mathrm{t}}$ : variable cost in the facility $\mathrm{n}$ and the year $\mathrm{t}$;

$\mathrm{E}_{\mathrm{t}}$ :electricity generation in the year $\mathrm{t}$;

$\mathrm{r}$ : discount rate (5\%);

$\mathrm{C}_{\text {dep_n,t }}$ : depreciation of facility $\mathrm{n}$ and year $\mathrm{t}$;

$\mathrm{C}_{\text {tax } \_ \text {n,t }}$ : fixed asset tax of facility $\mathrm{n}$ and year $\mathrm{t}$;

$\mathrm{C}_{\mathrm{ins} \_\mathrm{n}, \mathrm{t}}$ : insurance cost of facility $\mathrm{n}$ and year $\mathrm{t}$;

$\mathrm{C}_{\text {gen_n, }}$ : general and administration cost of facility $\mathrm{n}$ and year t;

$\mathrm{C}_{\text {lab_n, } \mathrm{n}}$ : labor cost of facility $\mathrm{n}$ and year $\mathrm{t}$;

$\mathrm{C}_{\text {rep_nn, }}$ : repair cost of facility $\mathrm{n}$ and year $\mathrm{t}$;

$\mathrm{C}_{\text {elec_n,t }}$ : electricity cost of facility $\mathrm{n}$ and year $\mathrm{t}$;

$\mathrm{C}_{\text {fuel_n,t }}$ : fuel cost of facility $\mathrm{n}$ and year $\mathrm{t}$ (if necessary);

$\mathrm{C}_{\text {tol_n, } \mathrm{n}}$ : make-up toluene of facility $\mathrm{n}$ and year $\mathrm{t}$ (if necessary);

$\mathrm{r}_{\mathrm{tax}}$ : fixed asset tax rate;

$\mathrm{r}_{\text {ins }}$ : insurance rate;

$\mathrm{r}_{\mathrm{gen}}$ : general and administration cost rate;

$\mathrm{r}_{\text {lab }}$ : labor cost rate;

$\mathrm{r}_{\text {rep }}$ : repair cost rate ;

$\mathrm{V}_{\text {book_n,t }}$ : book value of facility $n$ and year $t$;

$\mathrm{C}_{\text {const_n }}$ : construction cost of facility $\mathrm{n}$.

The fixed cost of the facility in each year consists of depreciation, fixed asset tax, insurance, general and administration cost, labor cost and repair cost. Fixed asset cost rate is assumed to be $1.4 \%$ though tax rates vary in each country. The capital cost rate is neglected because the rate is thought to be set by each company or organization on the basis of its strategy and the objective of this study is to evaluate the cost of the system. General and administration cost rate, labor cost rate and repair cost rate are assumed taking account of practical values in Japan ${ }^{15)}$. The fixed asset cost is the product of the book value and the tax rate. Insurance, general and administration, labor and repair costs are the products of their rates and the construction cost of the facility, respectively. The variable cost includes renewable electricity, heavy oil as fuels for $\mathrm{OCH}$ tankers and dehydrogenation, and makeup toluene. It is assumed that electricity used for equipment such as pumps in the facilities are from renewable energy. The cost of heavy oil and toluene are set to be $795.5 \mathrm{USD} / \mathrm{t}$ and 350 $\mathrm{USD} / \mathrm{kL}$, respectively.

To reduce the whole system cost, the following measures were done.

(1) Reconsideration of unit capacities

Unit capacities such as liquefaction plants, LH2 tanker and chemical tanker were reconsidered. It is assumed that the construction cost changes with scale effect (i.e. the 2/3-power law) as the capacity of the facility changes. The capacity and energy consumption of the liquefaction 
plant was set to be $90 \mathrm{t} /$ day and $0.55 \mathrm{kWh} / \mathrm{Nm}^{3)}{ }^{16)}$. The capacities of LH2 and OCH tankers were 200,000 $\mathrm{m}^{3}$ in our earlier studies ${ }^{9}{ }^{10}$. . However, smaller tanker (i.e. more tankers) can shorten interval of tankers. This results in decrease of storage capacities in unloading ports of both LH2 and OCH systems.

(2) Extension of durable year for facilities

In our earlier studies ${ }^{91}{ }^{10}$, durable year were set as same as that required by law. In general, large scale chemical plants and power plants are utilized for dozens of years which are longer than their legal durable years. The depreciation year of each facility is extended as twice required by law in this study. For example, in the literature ${ }^{17}$, the list of liquefiers includes start years of operation. According to the list, 16 of 29 liquefiers are in operation for more than 20 years that is twice of the legal durable year.

(3) Decrease of storage capacities in the unloading port

The stored amount in the unloading port is the amount consumed in the hydrogen power plant for 30 days plus a half of duration till the next tanker comes in our earlier studies ${ }^{9)}{ }^{10)}$. The stored hydrogen in the unloading port is reduced to the consumed amount for 20 days in the reduced cost case.

(4) Tuning the whole system;

The systems were tuned to achieve no excess capacities in systems within the range of technically feasible.

\section{Results}

Fig. 2 shows the result of electricity costs for the LH2 system in the case of $10,000 \mathrm{~km}$. Although the cost does not include transmission and distribution cost of electricity inside of Japan, the costs of electricity are reduced to the range of the present electricity price in Japan by setting parameters properly. The upper and lower limits of the electricity cost in Japan are for industry and households, respectively ${ }^{18}$. The cost decreased to 0.18 from $0.26 \mathrm{USD} / \mathrm{kWh}$. Extension of durable years and decrease of storage capacity have a large effect on cost reduction. In other words, appropriate maintenances of facilities and the turnover rate of storage tanks in the unloading port is important.

Fig. 3 shows the result of electricity costs for the $\mathrm{OCH}$ system in the case of $10,000 \mathrm{~km}$. The cost decreased to 0.20 from $0.24 \mathrm{USD} / \mathrm{kWh}$. Change of durable years has some effect on cost reduction. The cost of dehydrogenation is still relatively high. This is because a fraction of running cost is relatively high in the $\mathrm{OCH}$ system compared with the LH2 system.

The cost of electricity of renewable energy still

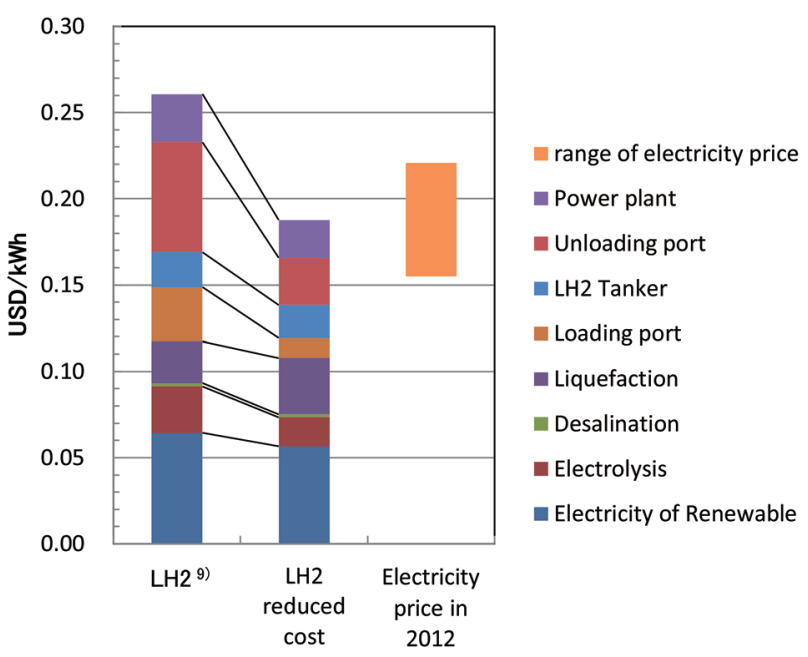

Fig. 2 Result of cost optimization for the liquefied hydrogen system

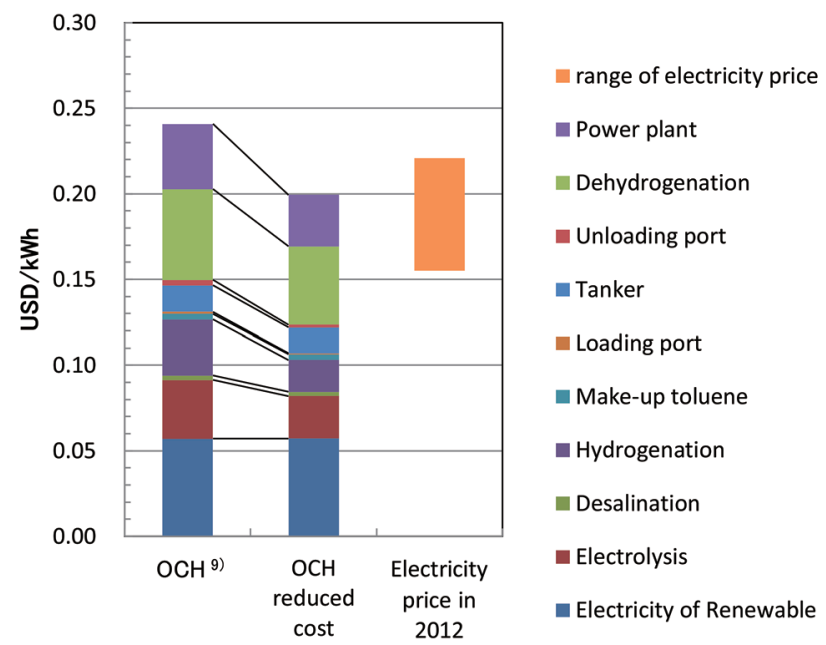

Fig. 3 Result of cost optimization for the organic chemical hydride system

accounts for approximately $30 \%$ of the total re-electrification cost of both systems. Under the condition that averaged electricity price of large hydropower is $0.105 \mathrm{USD} / \mathrm{kWh}^{11}$, electricity costs of both systems are approximately 44 cent/kWh. Therefore in addition to long distance transport technologies of low cost, affordable electricity from renewable energy is desired.

Fig. 4 shows distance dependence of the electricity cost transported to Japan using liquefied hydrogen and organic chemical hydride. The breakeven point between the electricity cost of the systems using HVDC and chemicals moves around $3,000 \mathrm{~km}$ from $4,000 \mathrm{~km}$ as a result of cost reduction of both $\mathrm{LH} 2$ and $\mathrm{OCH}$ systems. Costs of both systems increase with distance because the storage capacity of systems also increases with distance. The costs were improved by 0.04 - $0.09 \mathrm{USD} / \mathrm{kWh}$ compared with our previous study ${ }^{8}$. The costs are in the range of electricity 


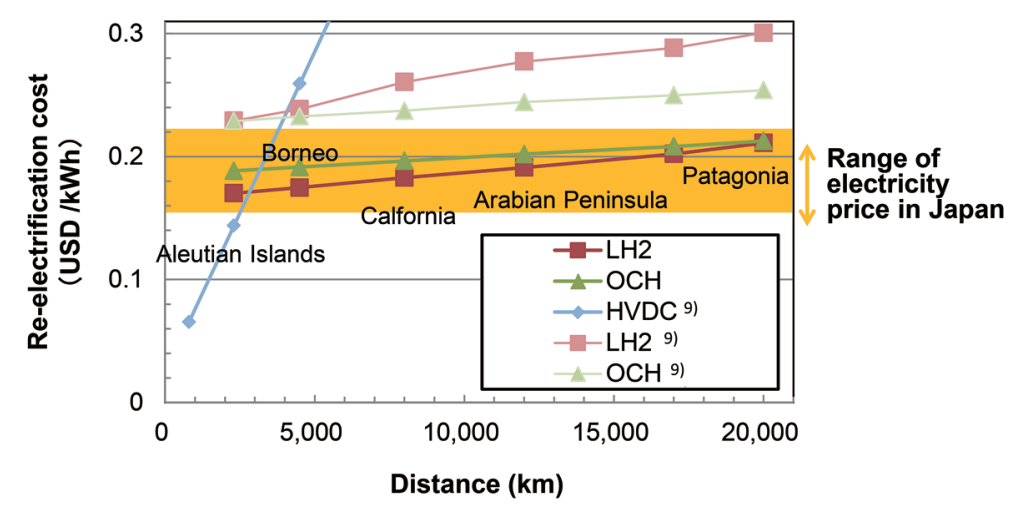

Fig. 4 Distance dependence of the re-electrification cost transported to Japan using liquefied hydrogen and organic chemical hydride. The orange area shows the price range of electricity prices of Japan in 2012

price in Japan.

\section{Conclusion}

Evaluation and comparison of intercontinental renewable energy transportation systems has been carried out in this paper. Cost reduction was done mainly by reconsidering unit capacities, extension of durable years, decrease of storage capacities of systems and tuning the whole system. It has been found that the electricity costs evaluated in this study are the range of 0.17-0.21 USD/ kWh and improved by 0.04 - 0.09 USD/kWh compared with our previous study. Therefore, the systems considered in this system are promising especially for Japan under the condition that renewable energy of low cost is available in foreign regions. Continuous efforts are strongly recommended to realize these systems. Therefore, large scale demonstration projects are necessary to deploy these systems. Financial incentives for these systems such as Feed in Tariff program should be considered after the demonstration.

\section{References}

1) EQHHPP Phase II feasibility study final report, Volume II Technical report, 1991

2) NEDO, Report of WE-NET Subtask 3, NEDO- WENET-9431,1995 (in Japanese)

3) Kaske, G. et al., International journal of hydrogen energy, 16, 105-114 (1991)

4) Hijikata, T., International journal of hydrogen energy, 27, 115-129 (2002)

5) Trans-Mediterranean Interconnection for Concentrating Solar Power Final Report, German Aerospace Center
(DLR), 2006

6) Wietschel, M.; Hasenauer, U., Renewable Energy, 32, 2129 (2007)

7) Stiller, C. et al., Energy, 33, 1623-1633 (2008)

8) Tiechmann, D. et al., International Journal of Hydrogen Energy, 37, 18118-18132 (2012)

9) Ishimoto, Y. et al., Proceedings of Renewable Energy 2010, 27 June - 2 July 2010, Yokohama, Japan

10) Ishimoto, Y. et al., Proceedings of World Hydrogen Energy Convention, 14-16, September 2011, Glasgow, UK

11) $\mathrm{ABB}$, The longest transmission link in the world 2,375 kilometers, http://new.abb.com/systems/hvdc/ references/rio-madeira, (Last access: 2015.5.25)

12) The International Renewable Energy Agency (IRENA), RENEWABLE ENERGY TECHNOLOGIES: COST ANALYSIS SERIES, Volume 1: Power Sector, Issue 3/5, Hydropower, 2012

13) NEDO, Fuel Cells and Hydrogen Technologies Road Map 2010, 2010 (in Japanese)

14) NEA/IEA/OECD, Projected Costs of Generating Electricity, pp.173-175, 2005

15) NEDO, Report on subtask3 in WE-NET project, NEDOWE-NET-9431, 1995, in Japanese

16) NEDO, Feasibility Study to Realize a Future Energy System (Hydrogen Supply Chain) Using Carbon-free Fuel Derived from Low Rank Coal (FY2012 - FY2013) Final Report implemented by Kawasaki Heavy Industries, 2012, in Japanese

17) Krasae-in, S. et al., International Journal of Hydrogen Energy, 35, 4524-4533 (2010)

18) IEA, Energy prices and taxes third quarter 2013, 2013 